\title{
Neutralność czy zaangażowanie? Recenzja szóstego numeru antydyscyplinarnego czasopisma „Stan Rzeczy”
}

Tytuł i numer czasopisma: Stan Rzeczy / 06 Wydawnictwo: Instytut Socjologii Uniwersytetu Warszawskiego

Rok wydania: 2014

\section{Mikołaj Raczyński}

Instytut Filozofii

Uniwersytet Warszawski

mikola.raczynski@gmail.com

Przyjęto: 14 stycznia; zaakceptowano: 27 stycznia.

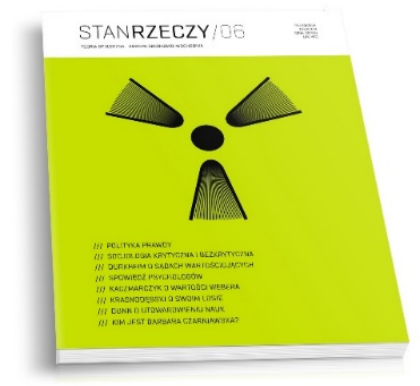

\begin{abstract}
Abstrakt
Autor poddaje recenzji i krótko komentuje szósty numer antydyscyplinarnego czasopisma „Stan Rzeczy”, który poświęcony jest zarówno roli naukowców, jak i socjologii jako nauki krytycznej. Punktem odniesienia dla publikowanych w periodyku tekstów są postacie Witolda Gombrowicza i Pierre’a Bourdieu jako egzemplifikacje socjologii zaangażowanej oraz uprawianej $\mathrm{z}$ academickiego dystansu.

Słowa kluczowe: socjologia; nauka; socjologia krytyczna; etyka; nauki społeczne.

Przedmiotem recenzji jest szósty numer antydyscyplinarnego czasopisma „Stan Rzeczy” wydawanego przez Instytut Socjologii Uniwersytetu Warszawskiego. Z charakterystyką samego pisma czytelnicy mieli już okazję zapoznać się przy recenzji premierowego numeru „Stanu Rzeczy” (Brzostek i Wachowski, 2013), dlatego w niniejszym tekście ograniczę się jedynie do - momentami krytycznego - omówienia wybranych elementów danego wydania.
\end{abstract}


Przewodnim tematem numeru jest poszukiwanie odpowiedzi na pytanie, które nie wprost w tekście otwierającym sformułował redaktor naczelny czasopisma Michał Łuczewski. Na potrzeby recenzji możemy je wyartykułować tak: czy socjolog (albo nawet szerzej naukowiec) powinien być zaangażowany w życie społeczne, czy pozostawać neutralnym? Najkrócej rzecz ujmując: dystans czy zaangażowanie, życie czy teoria, Gombrowicz czy Bourdieu? Biorąc pod uwagę szeroko rozumianą sytuację społeczno-polityczną $\mathrm{w}$ wielu krajach świata (także w Polsce), pytanie to wydaje się być niezwykle aktualne. W dyskusjach polityków i publicystów często możemy usłyszeć odwołania do tego czy innego filozofa, socjologa, czy politologa. Dla zobrazowania tego typu sytuacji wystarczy przytoczyć chociażby koncepcje końca historii Francisa Fukuyamy (zob. Fukuyama, 2017), końca ideologii Daniela Bella (zob. Bell, 1966) czy zderzenie cywilizacji Samuela Huntingtona (zob. Huntington, 2001) bardzo często przytaczane w dyskursach społecznych (w tym miejscu muszę abstrahować od prawidłowości interpretacji, które bardzo często przyprawiają specjalistów o zawroty głowy). Czy naukowcy powinni angażować się w życie społeczne? A jeśli tak, to jaka powinna być ich rola? Wydaje się, że to dwie podstawowe kwestie rozważane przez autorów szóstego numeru „Stanu Rzeczy”.

Czasopismo składa się z bardzo różnorodnych tekstów i to nie tylko pod względem merytorycznym, ale także metodologicznym i rodzajowym. Możemy zapoznać się z tłumaczeniem tekstu klasycznego, analizami znanych koncepcji, opisami badań socjologicznych, projektami filozoficznym i wywiadami.

Tekstem otwierającym numer jest tłumaczenie wykładu Emila Durkheima „Sądy wartościujące i sądy o rzeczywistości” wygłoszonego 6 kwietnia 1911 roku na Międzynarodowym Kongresie Filozoficznym w Bolonii. Podsumowując swoje rozważania francuski naukowiec stwierdza: „zadaniem socjologa powinno być przywrócenie ideału naturze w każdej formie, zachowując jednocześnie wszystkie jego wyróżniające cechy. I jeśli zadanie to wydaje mu się możliwe do wykonania, to dlatego że społeczeństwo spełnia wszystkie warunki potrzebne do tego, by zdać sprawę z tych sprzecznych cech” (Durkheim, 2014, s. 21). Ta zwięzła i skrótowa rekapitulacja wykładu Durkheima jest dobrym wprowadzeniem do omówienia dalszych części czasopisma.

Warty uwagi jest moim zdaniem wywiad Aleksandry Leyk z Elizabeth Dunn, profesor antropologii, autorką głośnej kilka lat temu książki Prywatyzując Polskę. Rozmówczyni zwraca uwagę na logikę biznesową, która w pełni opanowała świat nauki, czego skutkiem jest przekształcenie się krytycznie myślących naukowców w zakontraktowanych dostarczycieli danych dla agencji rządowych albo korporacji. Taka sytuacja jest groźna, gdyż ciężkie do powtórzenia mogą być ruchy takie jak The Occupy Movement, które zdaniem Dunn w znaczącym stopniu mogły zaistnieć głównie dzięki otwartemu na nowe interpretacje zapleczu akademickiemu. Amerykańska antropolożka wyraża to, co - jak się wydaje - myśli większość akademików i mówi wprost: „Europejski 
system oceny badań doprowadził do tego, że praca na uniwersytecie jest jak praca w fabryce. Liczy się tylko sklecanie artykułów, bez znaczenia czy są mądre, czy głupie, genialne i innowacyjne czy też nadają się tylko do śmieci i trafiają do pisma, którego nikt nie czyta” (Dunn, 2014, s. 90).

Oczywiście podobną opinię moglibyśmy usłyszeć od wielu innych badaczy, największą jednak wartością wywiadu jest to, że rozmówczyni stara się znaleźć receptę, która umożliwiłaby wyjście z tej, wydawałoby się, patowej sytuacji. Co niezwykle istotne rada Dunn dla akademików jest bardzo prosta: „piszcie przystępnym językiem”. Ta klarowna z pozoru sugestia w praktyce nie jest aż tak łatwa do wprowadzenia w życie, lecz nie ma innej drogi pozwalającej rozwijać się nauce, niż rozszerzenie grona odbiorców i zainteresowanie nauką kolejnych pokoleń. Antropolożka bezpośrednio wyraża swoje pretensje do naukowców, którzy wycofują się z debat publicznych, oddając - tak istotne - zadanie komentowania rzeczywistości publicystom i pisarzom, a „przecież ci ludzie wykonują naszą pracę!”.

Kolejnym ciekawym tekstem jest wywiad ze Zdzisławem Krasnodębskim. Rozmowa ta ma podwójną wartość, z jednej strony jest interesująca poznawczo, natomiast $z$ drugiej strony warto pamiętać, że rozmówca jest doskonałym przykładem łączenia pracy naukowej z działalnością polityczną (jest posłem do Parlamentu Europejskiego VIII kadencji), a to przecież jeden z głównych tematów omawianego czasopisma. Podczas polemiki między prowadzącymi wywiad Michałem Łuczewskim i Jakubem Motrenko a Krasnodębskim poza wieloma ciekawymi historiami z okresu działania Solidarności, możemy poznać zdanie autora klasycznej już Demokracji peryferii na temat tego, „o co chodzi w nauce”. Według socjologa naukowcy powinni lepiej wyczuwać rzeczywistość i jej dynamikę, a metody jak tego dokonują są sprawą wtórną. Właśnie wedle takiej reguły stara się funkcjonować europoseł Prawa i Sprawiedliwości, o czym świadczyć mają zarówno jego artykuły naukowe, jak i publicystyka polityczna.

W jednym z następnych tekstów Justyna Kajta przeprowadza coś, co moglibyśmy nazwać meta-analizą badań prowadzonych nad ruchami nacjonalistycznymi. Zważywszy na wydarzenia mające miejsce w zarówno Polsce, jak i w wielu miejscach świata, gdzie rośnie poparcie dla ugrupowań populistyczno-nacjonalistycznych i odwołujących się do symboli narodowych, jest to temat niezwykle aktualny. Czy socjologowie powinni zajmować się ruchami nacjonalistycznymi? Jeśli tak, to czy badania te mają prowadzić naukowcy popierający lub nawet zaangażowani w te ruchy, czy raczej osoby neutralnie nastawione? Wydaje się, że to są podstawowe pytania, z którymi mierzy się autorka tekstu. Odpowiedzi udzielone przez Kajtę mogą dziwić, gdyż stwierdza ona, że socjolog, którego poglądy są odmienne od badanej grupy pomimo zdiagnozowania problemu nie będzie stawiał za cel pomocy, powinien ograniczyć się do tradycyjnej socjologii publicznej. Stwierdzenie takie początkowo może 
wydawać się sprzeczne z tradycyjnym poglądem na naukowość opartą na neutralności i faktach przynajmniej sprawiających wrażenie obiektywnych. Jednak wydaje się, że autorce artykułu chodzi o promowanie socjologii zaangażowanej, dzięki której nie tylko otrzymujemy wyniki badań, ale mamy szansę pomóc diagnozowanym i zarazem w pewien sposób wykluczonym grupom, do jakich zaliczyć można nacjonalistów.

Jednym z podstawowych założeń teorii systemu światowego Immanuela Wallersteina jest wprowadzenie rozróżnienia na państwa centralne, peryferia i półperyferia. Oczywiście nie ma tutaj miejsca na głębszą analizę tego szeroko omawianego - projektu. Chciałbym jedynie przypomnieć, że najprościej rzecz ujmując państwa centralne to potęgi militarne i gospodarcze, które narzucają warunki wymiany międzynarodowej, peryferia to państwa mniej rozwinięte, najczęściej kolonie bądź państwa, z którymi centrum prowadzi niezrównoważoną wymianę handlową, natomiast półperyferia to mniejsze państwa należące do centrów światowego rozwoju oraz przodujące państwa peryferii (Wallerstein, 2007). Do tej monumentalnej już koncepcji wracam tylko dlatego, że jest ona podłożem tezy stawianej przez Tomasza Warczoka i Tomasza Zaryckiego w artykule (Ukryte) zaangażowanie i (pozorna) neutralność: strukturalne ograniczenia rozwoju socjologii krytycznej $w$ warunkach półperyferyjnych. Autorzy stwierdzają tam, że „w warunkach (pół)peryferyjnych, do jakich można odnieść pozycję Polski, dominującą rolę odgrywają w socjologii nurty ściśle powiązane z logiką pola politycznego, a szerzej tak zwanego pola władzy" (Warczok i Zarycki, 2014, s. 129). W takich warunkach uprawianie socjologii krytycznej autorzy uważają za utrudnione, gdyż dominuje socjologia nazywana przez naukowców służebną. Wydaje się, że teza ta jest nazbyt radykalna, gdyż bez większego problemu w polskiej socjologii możemy znaleźć teksty krytyczne, wystarczy wymienić chociażby publikacje Macieja Gduli, Przemysława Sadury czy Jana Sowy. Co ważne nie są to postacie niszowe, wręcz przeciwnie - zajęcia przez nich prowadzone wzbudzają ogromne zainteresowanie, podobnie zresztą jak teksty przez nich wydawane, które omawia się na licznych uniwersyteckich oraz pozaakademickich seminariach. Zarycki i Warczok z jednej strony to zauważają, jednak mimo wszystko twierdzą, że $w$ nauce dominuje logika pro- i antycentrowa. Teza ta jest z pewnością ciekawa, ale wymaga doprecyzowania, gdyż wymienieni już wcześniej Gdula, Sadura i Sowa wydają się udowadniać, że można w neutralny sposób uprawiać naukę i nie robić tego ze zmarginalizowanej pozycji.

Następny dział czasopisma nosi nazwę „Próby projektu”, dystynkcja ta powoduje, że zmieniają się oczekiwania czytelnika, który po wcześniejszych „Próbach opisu” teraz liczy na coś więcej niż nawet bardzo rzetelna i dobrze udokumentowana analiza. Jednak czytając pierwszy tekst tego działu autorstwa Jana Winczorka możemy być zawiedzeni, gdyż otrzymujemy przede wszystkim analizę. Oczywiście należy podkreślić, że autor $\mathrm{w}$ zrozumiały 
i ciekawy sposób porusza interesujący temat „nudnej prawdy” w nauce. Czytelnik liczący na „próbę projektu”, na nową „wielką narrację” nie znajdzie jej jednak w tym tekście. Zresztą podobnie jest z kolejnymi dwoma artykułami Magdaleny Nowickiej i Radosława Sojaka, których raczej nie można zaliczyć do tekstów-projektów, są to artykuły krytyczne wobec jakichkolwiek projektów. Oczywiście nie jest winą naukowców, że ich teksty zostały niejako przypisane do działu, od którego można wymagać najwięcej. Była to zapewne decyzja wydawcy, która w nieumyślny sposób może tym - co warte podkreślenia wartościowym - tekstom zaszkodzić. Mimo wszystko postaramy się z owych prób wyciągnąć jakieś zalążki projektów albo, może trafniej, anty-projektów. Na wstępie warto zaznaczyć niezwykłą umiejętność całej trójki autorów (Magdaleny Nowickiej, Jana Winczorka i Radosława Sojaka) nadawania tytułów doskonale przyciągających uwagę. Przeglądając spis treści natrafiamy na „nudną prawdę”, „obietnicę emancypacji” i „terapię dyskursu publicznego”, co bez wątpienia zachęca do zgłębienia zagadnień.

Jak celnie w tekście wstępnym zauważa redaktor naczelny „Stanu Rzeczy”, Nowicka bardzo ogranicza nasze ambicje i praktycznie wprost stwierdza, że socjologia krytyczna jest nie tylko niemożliwa, ale także niepotrzebna (Łuczewski, 2014, s. 10). Jej zdaniem próba emancypacji może mieć nawet charakter negatywny i jest - co ciekawe - uzależniająca. Dlatego też według socjolożki „poszukiwanie dróg do emancypacji powinno pozostawić w badaczach i krytykach nieustający niedosyt i podejrzenie, że tropy, które obrali, być może są mylne” (Nowicka, 2014, s. 248).

Wzbudzającą jeszcze większą ciekawość tezę w swoim tekście postawił Winczorek. Socjolog w artykule w dużej mierze rozwiązującym zawiłości teorii Niklasa Luhmanna konstatuje, że prawdziwa nauka nie wnosi żadnej wartości dodanej i jej jedynie elementem nudnej prawdy, a jest tak dlatego, że kryteria uznawania czegoś za prawdę określane są przez sam system, który tego dokonuje. Zdaniem autora tekstu jest to jedno z najważniejszy osiągnięć „,badań systemowych”. Zupełnie abstrahując od oceny tych rozważań, to czy dochodząc do takiego wniosku możemy oczekiwać zapowiadanej przez nazwę działu „próby projektu"? Wydaje mi się, że nie, ale to w żaden sposób nie obniża wartości skądinąd niezwykle ciekawego tekstu.

Z kolei ostatni z trójki autorów piszących w tym dziale do kwestii podchodzi zupełnie inaczej, jak to Łuczewski nazwał w słowie wprowadzającym, „po gombrowiczowsku”. Dla Sojaka odwołującego się do socjologii Charlesa Wrighta Millsa nie ma żadnego neutralnego punktu widzenia, dlatego zaangażowanie się po jednej ze stron etycznego sporu jest koniecznością. Zdaniem autora artykułu człowiek nie ma czasu na dystansowanie się od swojej przeszłości i wyborów etycznych, a z tego powodu - nawet dla swojego spokoju moralnego - najlepszą drogą jest zaangażowanie. 
Już nawet takie niezwykle krótkie i uproszczone omówienie głównych tez tych trzech artykułów pokazuje, jak duże rozbieżności dzielą wyżej wymienionych autorów. Wydaje się, że jedyną kwestią, która łączy owe publikacje jest chęć i próba dyskusji na temat roli, jaką miałaby spełniać socjologia krytyczna, oczywiście jeśli stwierdzilibyśmy, że jest ona konieczna. Dlatego możemy uznać, że konsensus jest dużo łatwiejszy do uzyskania na meta-poziomie, niż w wyniku merytorycznej dyskusji.

W numerze znajdziemy również zapis debaty „Jak odnieść sukces w nauce (i nie stracić cnoty)?”, w ramach której uczestnicy zastanawiali się nad poruszanymi w czasopiśmie problemami, takimi jak chociażby podpisywanie prac wieloautorskich tylko nazwiskiem uznanego profesora czy relacja mistrz-uczeń we współczesnej nauce. W toku dyskusji pojawiło się wiele interesujących opinii, jednak wydaje się, że tą, która przeważyła i uzyskała największe poparcie wyraził Edmund Wnuk-Lipiński. Według niego zarówno naukowcy, jak i odbiorcy treści nie mogą abstrahować od tego, że wszyscy badacze są ludźmi i w związku z tym mają własne systemy wartości. Najwyższy czas jasno stwierdzić, że „neutralny badacz nie istnieje, value-free sociology jest ideałem”. Najbardziej sprawiedliwą postawą zdaniem Wnuka-Lipińskiego (z którym się zgadzam) jest zatem jasne przedstawienie swojej hierarchii wartości, która w sytuacjach granicznych pozwoli opowiedzieć się po stronie bliższej ideowo. Jako przykład takich warunków historycznych zmarły krótko po tej debacie socjolog wskazał czasy Solidarności, kiedy naukowcy w znaczącym stopniu zaangażowali się w życie polityczne. Oczywiście zaangażowanie się po jednej ze stron może wiązać się z podziałem środowiska akademickiego, gdyż adwersarze mogą opowiadać się za inną wersją dobra. Jednak według Wnuka-Lipińskiego „takie rzeczy powinno czuć się intuicyjnie”.

Dyskusja ta może prowadzić także do rozważań dotyczących nie tylko tego, kto jest autorem badań naukowych, ale także tego, kto je finansuje. Abstrahując od wyżej wymienianych sytuacji granicznych wydaje się, że naukowiec w swoich badaniach powinien kierować się rzetelnością i starać się zachować możliwie jak największą obiektywność. W tym punkcie warto na chwilę powrócić do coraz bardziej zauważalnej w nauce logiki biznesowej, o czym w kilka akapitów wcześniej wspominanym wywiadzie mówiła Dunn. Co ważne logika ta przejawia się nie tylko w pogoni naukowców za jak największą liczbą publikacji, lecz i w funkcjonowaniu korporacji. Przykładem mogą być chociażby firmy farmaceutyczne, które według obliczeń przeprowadzonych przez EU R\&D Scoreboard w 2016 roku w Polsce na badania i rozwój przeznaczyły 132 mld euro (Rynek Zdrowia, 2017). Wydawać by się mogło, że zjawisko to można ocenić jedynie pozytywnie, doświadczenie nakazuje jednak zachować w tym względzie szczególną ostrożność. Badania kliniczne prowadzone przez firmy farmaceutyczne (a w rzeczywistości przez naukowców przez te firmy zatrudnionych) nie zawsze są oficjalnie zgłaszane. Eksperci uważają, że nawet połowa z nich nigdy nie jest ujawniana, a dotyczy to szczególnie tych, które wypadły 
negatywnie. Do urzędów zajmujących się zatwierdzaniem leków do użycia zgłaszane są przede wszystkim te badania, które wypadły pozytywnie. Jak co jakiś czas informują media i organizacje się tym zajmujące, zdarza się, że firmy ukrywają wyniki badań, które do tego stopnia dyskredytują ich lek, że w ogóle nie powinien być zarejestrowany (Nauka w Polsce, 2015). Do tych kwestii w zamieszczonej w „Stanie Rzeczy” debacie odniósł się Maciej Żylicz, wskazując, że mimo ogromnych nakładów na badania kliniczne firmy farmaceutyczne nie rozwijają badań nad rzadkimi chorobami, gdyż na tym nie można wystarczająco dużo zarobić. Czy takie postępowanie jest zgodne z Mertonowskim ideałem nauki, wedle której wszyscy powinni być anonimowi i pracować dla wspólnego dobra? Zdecydowanie nie, jednakże finansowanie pracy naukowej ze środków publicznych jest na tyle utrudnione (i czasami niskie), że specjaliści $\mathrm{w}$ poszukiwaniu większych zarobków opuszczają sferę akademicką na rzecz pracy w korporacji. Problem ten w dalszym ciągu jest nierozwiązany, ale dyskusje (chociażby takie jak ta przedrukowana w „Stanie Rzeczy”) mogą pomóc i umożliwią przejście do etapu, który można nazwać świadomą niekompetencją.

Etyka we współczesnych badaniach naukowych nie jest zagadnieniem nowym. Już w opowiadaniach Stanisława Lema z lat 60. możemy znaleźć wiele podobnych wątków, przykładem są chociażby genialni konstruktorzy Trurl i Klapaucjusz (Lem, 2015). Są oni parą inżynierów o nadzwyczajnej wiedzy i niemal nadludzkich zdolnościach. Jednakże, co istotne w fabule stworzonej przez polskiego futurologa, podróżują po Wszechświecie, pomagając potrzebującym i obalając tyranów, najkrócej rzecz ujmując są opisywani jako dobrzy i praworządni. Nie wykorzystują swojej wiedzy tylko dla pomnażania pieniędzy (chociaż niezwykli odmawiać hojnych nagród), można stwierdzić, że wykonują pracę dla wspólnego dobra, dla nauki samej w sobie. Wydaje się, że Trurl i Klapaucjusz mogliby posłużyć jako wzór dla współczesnych naukowców, gdyż z jednej strony rywalizują na polu naukowym, ale z drugiej strony w kluczowych momentach są w stanie współpracować i tworzyć jako duet, bez wyróżniania żadnego z nich. Kwestię tę można porównać chociażby do wieloautorskiej pracy podpisanej nazwiskiem jedynie najbardziej znanego twórcy, który niejako zbiera wszystkie laury związane z ewentualnym sukcesem publikacji.

Omawiany numer „Stanu Rzeczy” bez wątpienia jest pełen interesujących artykułów. Co ważne mimo czasu upływającego od jego wydania, wszystkie teksty są $\mathrm{w}$ pełni aktualne, a tematy $\mathrm{w}$ nich poruszane $\mathrm{w}$ dalszym ciągu są i powinny być poddawane dyskusjom. Istotne jest również to, że autorzy publikujący w periodyku reprezentują różne środowiska badawcze, co jest bardzo dobrym potwierdzeniem realizacji celu, jaki stawiali przed sobą twórcy czasopisma. Z pewnością jest ono miejscem dialogu między socjologią a innymi dyscyplinami z kręgu nauk społecznych i humanistycznych. Na stronie internetowej „Stanu Rzeczy” wydawcy stwierdzają: „Umożliwiając dyskusję, chcemy 
promować nowatorskie i nieoczywiste ujęcia zjawisk społecznych. Jednocześnie odwołujemy się do chlubnych tradycji uprawiania socjologii na Uniwersytecie Warszawskim”. Artykuły zamieszczone w omawianym numerze w interesujący sposób analizują zadanie zarówno naukowców jako takich, jak i samej socjologii jako nauki krytycznej. Nam, czytelnikom owych tekstów nie pozostaje nic innego jak ustosunkowanie się do poruszanych problemów i próba ich rozwiązania. Może dzięki temu, jak stwierdza Łuczewski, „pewnego dnia wyjdziemy - być może - poza Bourdieu i Gombrowicza, którzy wiedzieli, czym jest zło, ale tylko przeczuwali, czym jest prawdziwe dobro” (Łuczewski, 2014). Czego życzę zarówno sobie, jak i wszystkim innym parającym się nauką.

\title{
Literatura
}

Bell, D. (1966). The end of ideology: On the exhaustion of political ideas in the fifties. New York, NY: The Free Press.

Brzostek, B., Wachowski, W. (2013). Do rzeczy - antydyscyplinarnie: Recenzja Stanu Rzeczy i refleksje recenzentów. Avant, 4(1), 292-300.

Fukuyama, F. (2017). Koniec historii i ostatni człowieka. (T. Bieroń, M. Wichrowski, tłum.). Kraków: Wydawnictwo Znak.

Huntington, S. (2001). Zderzenie cywilizacji i nowy kształt ładu światowego. (H. Jankowska, tłum.). Warszawa: Warszawskie Wydawnictwo Literackie Muza.

Lem, S. (2015). Cyberiada. Warszawa: Wydawnictwo Literackie.

Merton, R. K. (1972). Insiders and outsiders. A chapter in the sociology of knowledge. American Journal of Sociology, 78(1), 9-47.

Nauka w Polsce. (2015, 28 grudnia). Od 2016 r. większa jawność w badaniach klinicznych leków, Nauka w Polsce. Źródło: http://naukawpolsce.pap.pl/aktualnosci/news\%2C407730\%2Cod-2016-r-wieksza-jawnosc-w-badaniach-klinicznychlekow.html (data dostępu: 06.01.2017).

Rynek Zdrowia. (2017). Firmy farmaceutyczne liderem w wydatkach na badania i rozwój. Źródło: http://www.rynekzdrowia.pl/Badania-i-rozwoj/Firmy-farmaceutyczne-liderem-w-wydatkach-na-badania-i-rozwoj,176017,11.html (data dostępu: 05.01.2017).

Stan Rzeczy, 1(6). Źródło: http://www.stanrzeczy.edu.pl

Wallersteina, I. (2007). Analiza systemów-światów: Wprowadzenie. (K. Gawlicz, M. Starnawski, przeł.). Warszawa: Wydawnictwo Akademickie Dialog.

\section{Neutrality or commitment? A review of the journal issue}

\begin{abstract}
The author reviews and briefly comments on the sixth issue of the antidisciplinary journal Stan Rzeczy (State of Affairs) which is devoted to the role of scientists and sociology
\end{abstract}


as a critical science. Figures of Witold Gombrowicz and Pierre Bourdieu are used as benchmarks for texts published in the journal; they exemplify engaged sociology and sociology practiced from an academic distance.

Keywords: sociology; science; critical sociology; ethics; social sciences 